\title{
The Role of Properdin in Zymosan- and Escherichia coli-Induced Complement Activation
}

\author{
Morten Harboe $^{a}$, Peter Garred ${ }^{b}$, Julie K. Lindstad ${ }^{a}$, Anne Pharo ${ }^{a}$, Fredrik Müller ${ }^{c}$, Gregory \\ L. Stahld ${ }^{\mathrm{d}}$, John D. Lambris ${ }^{\mathrm{e}}$, and Tom Eirik Mollnes ${ }^{\mathrm{a},{ }^{*}}$ \\ anstitute of Immunology, University of Oslo and Oslo University Hospital, Rikshospitalet, \\ NO-0027 Oslo, Norway \\ ${ }^{b}$ Department of Clinical Immunology, section 7631 Rigshospitalet, Copenhagen University \\ Hospital, DK-2100 Copenhagen Ø, Denmark \\ 'Faculty of Medicine, University of Oslo and Department of Microbiology, Oslo University \\ Hospital, Rikshospitalet, NO-0027 Oslo, Norway \\ ${ }^{d}$ Center for Experimental Therapeutics and Reperfusion Injury, Harvard Medical School, Boston \\ MA 02115 \\ eDepartment of Pathology and Laboratory Medicine, University of Pennsylvania, Philadelphia PA \\ 19106
}

\section{Abstract}

Properdin is well-known as enhancer of the alternative complement amplification loop when $\mathrm{C} 3$ is activated, whereas its role as recognition molecule of exogenous pathogen-associated molecular patterns and initiator of complement activation is less understood. We therefore studied the role of properdin in activation of complement in normal human serum (NHS) by zymosan and various Escherichia coli strains. In ELISA, microtiter plates coated with zymosan induced efficient complement activation with deposition of $\mathrm{C} 4 \mathrm{~b}$ and TCC on the solid phase. Virtually no deposition of $\mathrm{C} 4 \mathrm{~b}$ or TCC was observed with MBL deficient serum. Reconstitution with purified MBL showed distinct activation in both readouts. In ELISA, NHS-induced deposition of properdin by zymosan was abolished by the $\mathrm{C} 3$ inhibiting peptide compstatin. Flow cytometry was used to further explore whether properdin acts as initial recognition molecule reacting directly with zymosan and three $E$. coli strains. Experiments reported by other authors were made with EGTA $\mathrm{Mg}^{++}$buffer permitting auto-activation of $\mathrm{C} 3$. We found inhibition by compstatin on these substrates indicating that properdin deposition depended on initial $\mathrm{C} 3 \mathrm{~b}$ deposition followed by properdin in a second step. Properdin released from human polymorphonuclear cells (PMN) stimulated with phorbol-myristate acetate did not bind to zymosan or E. coli, but when incubated in properdin-depleded serum this form of properdin bound efficiently to both substrates in a strictly C3-dependent manner, since the binding was abolished by compstatin. Collectively, these data indicate that properdin in serum as well as PMN-released properdin is unable to bind and initiate direct alternative pathway activation on these substrates.

*Corresponding author: Tel: +47 90630015, fax: +47 23073510, t.e.mollnes@medisin.uio.no.

Disclosures

The authors have no financial conflict of interest. 


\section{Introduction}

Zymosan which is a carbohydrate complex derived from yeast cell walls, is an essential reagent in studies of complement activation. Pillemer and his collaborators first described properdin providing evidence that zymosan-properdin complexes induced antibodyindependent complement activation $(1,2)$. Reaction between properdin and various bacterial polysaccharides was also reported. The findings were controversial at that time, difficult to reproduce, and with Pillemer's death (3-5) properdin was largely dismissed by the scientific community. The properdin system was reborn as the alternative pathway (AP) more than 20 years later $(2,4)$. Properdin is now denoted factor P (fP), and the current description of two different functions of fP $(2,6-9)$ has been a valuable basis for further studies and development in this area.

In the long-standing model, AP is slowly auto-activated by hydrolysis of $\mathrm{C} 3$ with exposure of the internal thioester bond, leading to an initial AP convertase which cleaves $\mathrm{C} 3$, and $\mathrm{C} 3 \mathrm{~b}$ is subsequently covalently attached to nearby targets. Bound $\mathrm{C} 3 \mathrm{~b}$ then binds to $\mathrm{fB}$, which is cleaved by $\mathrm{fD}$. The $\mathrm{Ba}$ fragment is released into the fluid phase. $\mathrm{Bb}$ remains as part of the $\mathrm{C} 3 \mathrm{bBb}$ complex, the potent AP C3 convertase, which splits more $\mathrm{C} 3$ resulting in selfamplification and generation of the $\mathrm{C} 5$ convertase $\mathrm{C} 3 \mathrm{bBbC} 3 \mathrm{~b}$. The $\mathrm{C} 3 \mathrm{bBb}$ complex is relatively unstable with a half-life of 90 seconds under physiological conditions $(10,11)$. fP associates with $\mathrm{C} 3 \mathrm{bBb}$, forming a more stable $\mathrm{C} 3 \mathrm{bBbP}$ complex $(12,13)$ with longer lasting enzyme activity essential for effective AP amplification. Notably, fP is the only known regulator of complement which enhances the activation, whereas all other regulatory proteins have inhibitory properties.

Evidence for the role of $\mathrm{fP}$ as a recognition molecule in AP started with experiments showing that purified fP bound to a biosensor surface could serve as a platform for in situ assembly of AP C3 convertases $(9,14)$. Extensive experiments indicating that AP is initiated by non-covalent attachment of fP to a target surface (2) were, however, performed in EGTA $\mathrm{Mg}^{++}$buffer in which the auto-activation ("tick-over") of C3 and the AP pathway amplification is intact. Thus, this system would permit continuous $\mathrm{C} 3 \mathrm{~b}$ deposition, making it difficult to demonstrate whether fP reacts as an initial recognition molecule of zymosan or subsequently binds after $\mathrm{C} 3 \mathrm{~b}$ deposition. Different reaction patterns of isolated $\mathrm{fP}, \mathrm{fP}$ in serum, and fP released from activated, degranulated neutrophils are essential in studies of this matter as pointed out previously $(15,16)$ and further described in our Results section.

In addition to mannose-binding lectin (MBL), ficolin-1 (M), ficolin-2 (L) and ficolin-3 (H) are recognition units in the lectin pathway (LP) (17-19). Like MBL, the ficolins react with $\mathrm{N}$-acetylglucosamine, but the fine carbohydrate binding specificity differs from MBL and they do not react with mannan $(19,20)$.

Compared with mannan with an extensive literature on reactivity and induction of LP activation, in particular initiated by MBL, less has been reported concerning the mechanisms involved in zymosan induced LP activation. An early study indicated interaction with proteins later identified as essential constituents of LP (21), while formal identification of LP activation by zymosan was first provided by Brouwer et al. (22).

Specific activation of the classical pathway (CP) by heat aggregated human IgG (HAIGG) has been extensively studied, while development of systems for specific activation of LP in close to physiologic conditions has encountered considerable difficulties. However, we have recently developed a system for specific activation of LP without involvement of the classical pathway (CP) and with no direct, initial AP activation, using mannan coating on the solid phase of ELISA plates and normal human serum (NHS) at high concentration (diluted 1:2) (20). Three main observations indicated LP specificity of this system: i) 
Mannan on the solid phase induced activation of NHS but not of MBL deficient serum, showing that MBL is required for the activation. ii) After reconstitution of MBL deficient serum with purified MBL, activation was obtained, showing that MBL is responsible for activation. iii) Monoclonal anti-MBL antibody 3F8, documented to inhibit MBL function (23), abolished the activation of NHS, showing that activation depends exclusively on MBL.

We have reported that AP amplification contributed to more than $80 \%$ of the final C5a generation after initial HAIGG induced activation highly specific for CP (24). In mannan induced LP activation AP amplification has been described by various authors $(21,22)$. In the system with highly specific LP activation of human whole serum (20), we also found that AP amplification is crucial for the downstream effect of initial LP activation, being responsible for more than $80 \%$ of TCC release into the fluid phase (25).

The purpose of the present study was to apply similar technology to characterize complement activation induced by zymosan and to explore whether fP in normal human serum as well as fP released from phorbol-myristate acetate (PMA) stimulated polymorphonuclear cells (PMN) act as initial recognition molecule reacting directly with zymosan or whole $E$. coli, thereby starting AP activation by itself. To obtain conditions with control of initial $\mathrm{C} 3$ activation, we studied the effect of the $\mathrm{C} 3$ inhibiting peptide compstatin (26-29) on fP deposition on zymosan and three different strains of "properdin-reactive" $E$. coli strains (2) by flow cytometry. The findings demonstrate that this peptide served to distinguish between initial direct fP-binding (30) and secondary fP-binding to C3b.

\section{Materials and Methods}

\section{Monoclonal antibodies}

Mouse anti-MBL mAbs 3F8 (IgG1 $x)$ and $1 \mathrm{C} 10$ (IgG2b) were raised by immunization with purified human MBL, reacting with MBL with high affinity. 3F8 reacts with a conformation dependent epitope in the hinge within the carbohydrate recognition domain (CRD) of MBL and inhibits MBL-dependent C3 deposition on mannan-coated plates completely at $10 \mu \mathrm{g} /$ $\mathrm{ml}$ NHS (23), while $1 \mathrm{C} 10$ reacts with another epitope being non-inhibiting (31). Mouse antihuman fD (clone 166-32, IgG1 $\mathrm{x}$ ) (32) and its isotype-matched control mAb (clone G3-519, anti-HIV gp120, IgG1 ) were kindly provided by Michael Fung. Inhibiting mouse antihuman $\mathrm{fP}$, clone A233 (IgG1 $\kappa$ ) raised by immunization with purified human $\mathrm{fP}$ was obtained from Quidel Corporation, San Diego, CA. Clone IS7 (IgG1 $\ltimes$ anti-human CD22) from Diatec Monoclonals AS (Oslo, Norway) was used as its isotype control. mAb aE11 reacting with a neoepitope exposed when $\mathrm{C} 9$ is incorporated in the terminal complement complex (TCC) (33) was obtained from Diatec Monoclonals. Clone 5A7 from Diatec Monoclonals was used as its IgG2a isotype control.

\section{Normal human serum, plasma, and purified protein and cells}

Normal human serum (NHS) was collected from nine healthy volunteers, all showing normal CP, LP and AP activity in the Wielisa total complement system screen assay (34). Prior to pooling, the sera were tested for LP activation after exposure to mannan on the solid phase $(0.5 \mu \mathrm{g} /$ well $)$ using solid phase TCC deposition as readout. Activation was obtained and TCC deposition was inhibited completely by $3 \mathrm{~F} 8 \mathrm{mAb}$ in all nine sera, excluding interference by $\mathrm{CP}$ activation due to complement fixing anti-mannan antibodies occurring in occasional sera $(20,35)$. Subsequently the sera were pooled and stored as aliquots at $-70^{\circ} \mathrm{C}$. The MBL concentration of the pool was $740 \mu \mathrm{g} / \mathrm{l}$. To approach physiological conditions in activation assays and to ensure a fully active AP NHS was used at a final dilution of 1:2, which was the lowest possible dilution to obtain a constant final concentration of serum after addition of buffer and mAbs. Normal human plasma (NHP) was prepared as follows: blood 
from a healthy volunteer, drawn into an evacuated sterile NUNC plastic tube containing lepirudin (Refludan, Pharmion, Copenhagen, Denmark) to provide $50 \mu \mathrm{g}$ lepirudin $/ \mathrm{ml}$ blood. After mixing, the tube was centrifuged for $15 \mathrm{~min}$ at $1400 \mathrm{~g}$ at $4^{\circ} \mathrm{C}$. The supernatant plasma was aliquoted and then frozen at $-70^{\circ} \mathrm{C}$ for later flow cytometry analysis.

Factor P-Depleted Serum (A339 Lot \# 8a) and purified factor P (A139 Lot \# 21a) were obtained from Complement Technology Inc, Tyler, TX. Factor P was quantified by the Human Properdin ELISA Kit (Cat. Nr. HK334) from Hycult biotech, Uden, The Netherlands, according to the instructions of the manufacturer. Purified plasma-derived MBL was obtained from Statens Serum Institut, Copenhagen, Denmark (36).

Polymorphonuclear (PMN) cells were isolated by density gradient centrifugation on Polymorphprep (Axis-Shield, Medinor, Oslo, Norway) according to the instructions of the manufacturer, and the cells (a total of $1 \times 10^{8}$ cells in a buffer volume of $2.6 \mathrm{ml}$ ) were activated by Phorbol-myristate acetate (PMA) (Cat.no. 79346, Sigma-Aldrich, St. Louis, MO) at final concentration $500 \mathrm{ng} / \mathrm{ml}$ in BSA-coated tubes for $37^{\circ} \mathrm{C}$ for $30 \mathrm{~min}$ on a cell roller. The fP concentration in the supernatant after stimulation was quantified in fP ELISA and found to be $6 \mu \mathrm{g} / \mathrm{ml}$.

\section{Bacteria}

E. coli strain D31m3, D31m4 and ED3869 were obtained from the E. coli Genetic Stock Center, Yale university, New Haven, CT and cultured on tryptose blood agar base medium (Oxoid, Basingstoke, UK) with $2 \%$ lactose and $0.5 \% \mathrm{NaCl}$, subsequently subcultured in Heart infusion broth (Becton Dickinson, Sparks, MD) and harvested during exponential growth before flow cytometry experiments.

\section{MBL deficient serum}

MBL deficient (MBLd) serum was selected from an MBL D/D (codon 52 variant in the $M B L 2$ gene) homozygous 35 year old healthy male with no anti-mannan antibodies. The serum had normal CP and AP activity in the Wielisa assay (34) and standard hemolytic assays. It contains dysfunctional low molecular weight MBL which cannot bind ligands nor activate the MBL complement system efficiently under physiological conditions (37). Reconstituting the serum with recombinant wild type MBL has previously shown that the capability of MASP-1/3 and MASP-2 to interact with MBL is normal as well as the capacity to deposit C4 (38).

\section{Zymosan induced activation of serum}

Zymosan A from Saccharomyces cerevisiae (Cat.no. Z4250 Sigma-Aldrich, Steinheim, Germany) in a $100 \mu \mathrm{l}$ volume was coated on Costar 3590 flat-bottomed polystyrene 96-well plates (Corning Inc, Corning, NY) in $50 \mathrm{mM} \mathrm{Na-carbonate} \mathrm{buffer} \mathrm{pH} 9.6$ overnight at room temperature and the fluid was removed. After washing, the remaining binding sites in the wells were saturated with a blocking buffer, PBS pH 7.4 containing $1 \%$ BSA (Cat.no. A8327, Sigma-Aldrich, St. Louis, MO) and $0.1 \%$ Tween 20 (Cat.no. P1379, Sigma-Aldrich, St. Louis, MO), for $1 \mathrm{~h}$ at $37^{\circ} \mathrm{C}$. After three times washing with PBS containing $0.1 \%$ Tween 20, $50 \mu \mathrm{l}$ NHS diluted $1: 2$ in veronal buffer $\mathrm{pH} 7.5$ containing $0.5 \mathrm{mM} \mathrm{MgCl}_{2}, 2 \mathrm{mM}$ $\mathrm{CaCl}_{2}, 0.05 \%$ Tween 20 and $0.1 \%$ gelatin (GVB++ buffer) was added to each well for complement activation for $30 \mathrm{~min}$ at $37^{\circ} \mathrm{C}$. To stop LP activation and to ensure complete inhibition of continuing background AP amplification the microtiter plate was incubated on ice and $10 \mu \mathrm{l}$ EDTA was added immediately to each well to a final concentration of $20 \mathrm{mM}$ before assay for activation products on the solid phase and in the supernatant (fluid phase). Coating with mannan on the solid phase for activation was done in the same way, as reported previously (20). 


\section{Readouts for activation products on the solid phase}

Deposition of MBL on the solid phase following activation was demonstrated in ELISA using polyclonal rabbit anti-human MBL2 antibody 1:50 (Atlas Antibodies AB, Stockholm, Sweden) obtained by immunization with PrEST technology $(39,40)$ followed by HRP conjugated donkey anti-rabbit Ig 1:1,000 (Amersham Biosciences, Little Chalfont, UK) with ABTS as substrate. The recombinant peptide used for immunization covered amino acids 102-240 of the MBL sequence (www.atlasantibodies.com), and antigenicity plot analysis (41) indicated a series of antibody-reactive epitopes in this area.

Deposition of $\mathrm{C} 4 \mathrm{~b}$ and $\mathrm{C} 3 \mathrm{~b}$ on the solid phase was demonstrated with polyclonal rabbit antihuman C4 (OSAO 194 1:10,000) and anti-human C3 (OSAP 192 1:40,000) antibodies (Dade Behring, Marburg, Germany), HRP conjugated donkey anti-rabbit Ig 1:2,000 and ABTS as substrate.

Deposition of $\mathrm{fP}$ on the solid phase in ELISA was with monoclonal anti-fP (Quidel A233 1:1000) with HRP conjugated $\mathrm{F}\left(\mathrm{ab}^{\prime}\right)_{2}$ anti-mouse IgG (GE Healthcare UK Ltd, Little Chalfont, UK, 1:1000) with ABTS as substrate. In inhibition experiments with mAbs, deposition of fP was demonstrated with polyclonal goat anti-human fP (A239 $45 \mathrm{mg} / \mathrm{ml}$ 1:1,000) (Complement Technology, Tyler, TX), HRP conjugated mouse anti-goat Ig 1:1,000 (Jackson ImmunoResearch Europe Ltd, Newmarket, Suffolk, UK) with ABTS as substrate.

Deposition of the terminal complement complex (TCC) was based on reaction with purified $\mathrm{mAb}$ aE11 (42)(1 mg/ml 1:6,000 in PBS with $0.2 \%$ Tween 20$)$ followed by biotinconjugated rat anti-mouse IgG2a mAb 1:1,000 (BD Biosciences Pharmingen, Erembodegem, Belgium) and HRP conjugated streptavidin 1:2,000 (Amersham) with ABTS as substrate, using OD values at $405 \mathrm{~nm}$ to represent the relative amount of deposited TCC in the wells.

\section{Readout for TCC in the fluid phase}

TCC in the fluid phase was measured by a double-antibody assay described in detail previously (33,43). Briefly, mAb aE11 was used as catching antibody, biotinylated anti-C6 mAb 9C4 (43) as detection antibody, HRP-labeled streptavidin (Amersham), and ABTS as substrate.

\section{Inhibition assays}

$\mathrm{mAbs}$ were added to serum followed by incubation for $5 \mathrm{~min}$ at room temperature prior to activation and assay. Optimal concentration was determined in pilot experiments, control antibody being used in the same amount. The amount of purified $\mathrm{mAb} /$ well is recorded as transformed to amount $/ \mathrm{ml}$ of undiluted serum, anti-MBL 3F8 at $20 \mu \mathrm{g} / \mathrm{ml}$, anti-MBL $1 \mathrm{C} 10$ at $20 \mu \mathrm{g} / \mathrm{ml}$, anti-fD $166-32$ at $10 \mu \mathrm{g} / \mathrm{ml}$, and anti-fP A233 at $20 \mu \mathrm{g} / \mathrm{ml}$.

The compstatin analogue (Ac-I[CV(1MeW)QDWGAHRC]T) with increased C3 inhibiting activity produced as previously described $(27,29)$ was used at $50 \mu \mathrm{M}$.

\section{Flow cytometry}

A FACSCalibur instrument, (Becton Dickinson, Franklin Lakes, NJ), was used for flow cytometry with FlowJo analysis software version 7.6.4 (Tree Star Inc., Ashland, OR). Zymosan A (Sigma Z-4250, Steinheim, Germany) was suspended in PBS with $1 \%$ BSA. Blocking was with $1 \%$ BSA in PBS pH 7.4 with $1 \%$ Tween 20 for $1 \mathrm{~h}$ at $37^{\circ} \mathrm{C}$. Subsequent washing at this and all later steps was in PBS with $0.1 \%$ BSA. The zymosan was resuspended in GVB++ buffer. Incubation with NHS $1: 2$ was at $37^{\circ} \mathrm{C}$ for $20 \mathrm{~min}$ in GVB++ buffer after 5 min preincubation with compstatin at a final concentration of $50 \mu \mathrm{M}$. To 
demonstrate binding of fP, the zymosan was incubated with monoclonal anti-fP (Cat. No. A233 Quidel) diluted 1:50 for $15 \mathrm{~min}$ at room temperature. The samples were washed twice, and further incubated with anti-mouse IgG ( $\mathrm{Fc}$ specific) FITC conjugated $\mathrm{F}\left(\mathrm{ab}^{\prime}\right)_{2}$ (Sigma F2772, Steinheim) diluted 1:50 for 15 min at room temp in the dark. The samples were washed twice, resuspended in PBS with $1 \%$ BSA, and put on ice until analysis in the flow cytometer. Gating was based on forward- and side scatter and 20,000 events acquired. For analysis of E. coli, the bacteria were washed and suspended in PBS with $0.1 \%$ BSA.

Blocking was with $1 \%$ BSA in PBS without Tween for $1 \mathrm{~h}$ at $20^{\circ} \mathrm{C}$. Subsequent washing at this and all later steps was in buffer without Tween to avoid interaction between Tween and lipids in the bacterial surface layer. Incubation with NHS $1: 2$ was in $\mathrm{GVB}++$ buffer at $37^{\circ} \mathrm{C}$ for $20 \mathrm{~min}$ after $5 \mathrm{~min}$ preincubation with compstatin at final concentration $50 \mu \mathrm{M}$. For analysis of TCC binding to E. coli the procedures were adjusted to obtain optimal conditions based on the experiments in ELISA. Gating was based on forward- and side scatter and 20,000 events were acquired.

\section{Statistics}

GraphPad Prism version 5 (GraphPad Software, San Diego, CA) was used for statistical analyses. Data were examined with analysis of variance (ANOVA), by one way ANOVA followed by the Bonferroni post-test, ANOVA with repeated measurements followed by Dunnett's multiple comparison test, and the student t-test as appropriate for the different experiments. A $p$-value of 0.05 was considered statistically significant.

\section{Ethics}

The study was approved by the Norwegian Government Regional Committee for Medical Research Ethics.

\section{Results}

\section{C4b and TCC deposition on zymosan and mannan by NHS and MBL deficient serum}

NHS induced efficient deposition of $\mathrm{C} 4 \mathrm{~b}$ and TCC on the solid phase in microtiter wells coated with zymosan or with mannan for comparison (Fig. 1A and B), consistent with activation of the whole cascade on both coatings. By contrast, virtually no deposition of $\mathrm{C} 4 \mathrm{~b}$ or TCC was seen with the MBL deficient (MBLd) serum, with a similar result obtained for zymosan and mannan. Reconstitution with purified MBL showed distinct activation with OD values in both readouts comparable to the values for NHS, after addition of $10 \mu \mathrm{g} \mathrm{MBL} /$ $\mathrm{ml}$ MBLd serum. C4b-values with MBLd was significantly lower than with NHS and MBLd $+\mathrm{MBL}(\mathrm{p}=0.0013$ and 0.004 , respectively) (Fig. 1A). TCC-values with MBLd was significantly lower than with NHS and MBLd+MBL ( $p=0.004$ and 0.0016 , respectively) (Fig 1.B). In all sets the difference of NHS vs MBLd+MBL was not significant. Similar observations were made regarding deposition of $\mathrm{C} 3 \mathrm{~b}$ on the solid phase and release of TCC into the fluid phase (data not shown).

A dose-dependent deposition of $\mathrm{C} 4 \mathrm{~b}$ on the solid phase was observed after activation of NHS by different amounts of zymosan on the solid phase (Fig. 2A). Addition of the inhibiting anti-MBL mAb 3F8 abolished $\mathrm{C} 4 \mathrm{~b}$ deposition at all zymosan concentrations, showing OD values similar to the negative buffer control, indicating that no direct, MBLindependent activation leading to $\mathrm{C} 4 \mathrm{~b}$ deposition occurred in this system. Interference by ficolin 1, 2 and 3 is not expected from recent information on their recognition specificity $(19,44-46)$. Addition of the non-inhibiting mAb $1 \mathrm{C} 10$ gave OD values similar to those obtained with NHS alone. The difference between NHS and NHS + 3F8 was statistically significant $(\mathrm{p}<0.05)$ while the difference between NHS and NHS $+1 \mathrm{C} 10$ was not significant. 
Deposition of MBL on the solid phase after zymosan induced activation was also completely inhibited with anti-MBL mAb 3F8 (Fig. 2B). The findings concerning statistics were the same as for Fig. 2A. Control experiments with mannan induced activation $(0.5 \mu \mathrm{g} / \mathrm{w})$ showed the same reaction pattern (in black).

\section{C3b deposition and TCC formation after zymosan induced activation and inhibition with anti-MBL}

The dose-dependent NHS mediated C3b deposition on zymosan (Fig. 3A, open circles) was substantially, but not completely, inhibited by anti-MBL mAb 3F8 (Fig. 3A, open squares), similar to the results observed with MBLd serum (Fig. 3A, closed diamonds), whereas the control anti-MBL mAb 1C10 values (Fig. 3A, open triangles) were similar to NHS. There was a highly significant difference between the curves of Fig. 3A ( $p<0.0001)$. Thus, the difference between NHS and NHS+3F8, and between NHS and MBLd were both significant $(\mathrm{p}<0.05)$, whereas the difference between NHS and NHS+1C10 was not significant. Notably, in a control with mannan on the coat, known to activate only LP in this system (20), the anti-MBL mAb 3F8 completely inhibited C3b deposition (Fig. 3A, closed square), indicating some MBL-independent activation of AP, as judged by $\mathrm{C} 3 \mathrm{~b}$ deposition, by zymosan but not by mannan.

Data on deposition of TCC on the solid phase (Fig. 3B) showed similarity to deposition of $\mathrm{C} 3 \mathrm{~b}$, but with less inhibition by anti-MBL mAb 3F8 on the zymosan coat, whereas the inhibition with anti-MBL mAb 3F8 completely inhibited the activation on mannan, again indicating additional, MBL-independent activation of AP by zymosan. There was a higly significant difference between the curves of Fig. 3B ( $p=0.0035)$, MBLd being significantly different from NHS ( $<$ 0.05). Release of TCC into the fluid phase is showed inhibition by MBLd only ( $<<0.05)$ (Fig. 3C).

\section{Effect of various complement inhibitors on factor $P$ deposition on solid-phase zymosan by NHS}

NHS induced a dose-dependent fP deposition on zymosan (Fig 4A, open circles), which was identical to that seen with the non-inhibitory anti-MBL mAb 1C10 (Fig 4A, open triangles), whereas anti-MBL mAb 3F8 inhibited the deposition incompletely (Fig 4A, open squares), similar to what was obtained with anti-fD (open diamonds). By contrast, anti-fP A233 completely abrogated fP deposition (Fig. 4A, inverted open triangles). There was a highly significant difference between the curves of Fig. 4A ( $\mathrm{p}<0.0001)$, reflected by significances between NHS and NHS+3F8 and between NHS and MBLd serum, and between NHS+antifD and NHS+anti-fP. Notably, in the control with mannan induced activation specifically activating LP in this system (Fig. 4A, black symbols), both anti-MBL mAb 3F8 (black square) and anti-fP (black inverted triangle) completely inhibited deposition of fP.

In ELISA, deposition of $\mathrm{fP}$ on solid-phase zymosan by NHS was completely inhibited by the $\mathrm{C} 3$ inhibiting peptide compstatin ( $\mathrm{p}=0.013$ ) (Fig. 4B) in marked contrast to the fully retained deposition of $\mathrm{C} 4 \mathrm{~b}$ generated earlier in the complement activation cascade ( $\mathrm{p}=0.95)$ (Fig. $4 \mathrm{C})$.

In separate ELISA experiments, deposition of C3b on solid phase zymosan by NHS was inhibited significantly $(\mathrm{p}<0.05)$ by anti-MBL mAb 3F8, but not by the control anti-MBL $\mathrm{mAb} 1 \mathrm{C} 10$ nor by the inhibiting anti-fP mAb A233 or its isotype control (Suppl. Fig. 1). These findings correspond to observations in an earlier study (6) indicating that fP is not essential for zymosan-induced AP complement activation. 


\section{Factor $\mathbf{P}$ deposition on zymosan by plasma and factor $\mathbf{P}$ depleted serum}

To supplement the ELISA experiments on fP deposition on the solid phase after zymosan induced activation of NHS (Fig. 4A and B), similar experiments were made with fP depleted (fPd) serum. With NHS high OD values for fP deposition were obtained and low values with fPd serum, increasing again after reconstitution with fP (Fig. 5A). The OD value of fPd serum was statistically different $(\mathrm{p}<0.05)$ from NHS and from $\mathrm{fP}$ reconstituted fPd serum $(n=6)$.

To study the reactivity of zymosan in as close to physiological conditions as possible, interaction with lepirudin plasma (NHP) was studied in flow cytometry using deposition of $\mathrm{fP}$ and TCC as readouts. The recombinant hirudin analogue lepirudin is a highly specific thrombin inhibitor and a suitable anticoagulant without adverse effects on complement in studies of the inflammatory response in whole blood and plasma (47-49). Deposition of fP on zymosan was substantial with mean fluorescence intensity (MFI) of 42 after activation of NHP (Fig. 5B, dark red curve). Compstatin inhibited the signal to MFI values identical to the isotype control (Fig. 5B, light red curve). The inhibition of fP deposition by compstatin was statistically significant $(\mathrm{p}<0.0001)(\mathrm{n}=6)$. fP deposition by fPd was identical to the isotype control and increased after reconstitution with $\mathrm{fP}$ (Figure 5, panel C). The individual MFI data are given in Supplementary Table I.

Deposition of TCC on zymosan after interaction with NHP was substantial with MFI 336 (Suppl. Fig 2, dark green curve). Compstatin inhibited this binding to MFI 6.5 (Suppl. Fig. 2, light green curve). The corresponding MFI values of the isotype control was 3.9 (Suppl. Fig. 2, black stipled line), confirming C3 dependence of TCC deposition. Similar experiments with NHS gave results corresponding fully to those obtained with NHP.

\section{Factor P deposition on E. coli by flow cytometry}

Incubation of $E$. coli strain D31m4 with NHS induced deposition of $\mathrm{fP}$ on the bacteria (Fig. 6A, dark red curve), which was blocked by compstatin (light red curve) giving MFI values similar to the isotype control (Supplementary Table I). The inhibition of fP deposition by compstatin was statistically significant $(\mathrm{p}<0.0001)(\mathrm{n}=6)$. Incubation of $E$. coli strain D31m4 with fPd serum gave an MFI value similar to the isotype control and increased after reconstitution with fP (Fig. 6B and Supplementary Table I). Similar results were found in two other E. coli strains (D31m3 and ED3869).

\section{Deposition of factor $\mathbf{P}$ released from human blood PMN cells on zymosan and $E$. coli}

Deposition of fP released from PMA activated PMN cells (PMNfP) on zymosan was studied in ELISA (Fig. 7A). No deposition of PMNfP alone was found, since the OD values were identical to the isotype control antibody. By contrast, MPNfP from this supernatant showed significant $(\mathrm{p}<0.0001)$ deposition when incubated in fPd serum. In turn, addition of compstatin inhibited this PMNfP deposition completely (Fig. 7A, Supplementary Table I), analogous to what was repeatedly observed in experiments with normal serum. Identical observations were made in flow cytometry regarding deposition of PMNfP on E. coli (Fig. 7B, C).

\section{Discussion}

In the present study we found that inhibition of fP binding in NHS and lepirudin plasma to zymosan and to E. coli by compstatin served to distinguish between primary binding of fP, consistent with $\mathrm{fP}$ as a recognition molecule, and secondary binding to $\mathrm{C} 3 \mathrm{~b}$ initially formed in the tick-over reaction, consistent with $\mathrm{fP}$ as an amplification molecule. In our experiments we consistently found that fP both from human serum and released from activated PMN 
cells did not bind directly to zymosan or E. coli, but that binding of fP was dependent on initial $\mathrm{C} 3 \mathrm{~b}$ binding.

The amplification function of $\mathrm{fP}$ is well established, whereas a direct activation of AP by fP recognition is a current topic of investigation. The amplification function is associated with the unstable $\mathrm{C} 3 \mathrm{bBb}$ complex in AP $(10,11)$ interacting with fP to form a more stable C3bBbP complex (12) with longer lasting enzyme activity essential for effective AP amplification. The dependency of CP and LP on AP amplification is similar. Thus, in our earlier study, anti-fD mAb inhibited more than $80 \%$ of $\mathrm{C} 5 \mathrm{a}$ and TCC release into the fluid phase after HAIGG induced activation of CP (24) similar to data later found for LP (25) and corresponding to recent detailed structural studies showing analogous interactions in the initiating complexes of CP and LP (50).

Evidence for the role of $\mathrm{fP}$ as a recognition molecule in AP started with experiments showing that purified fP bound to a biosensor surface could serve as a platform for in situ assembly of AP C3 convertases $(9,14)$. Extensive further experiments indicating that AP is initiated by non-covalent attachment of fP to a target surface (2) were performed in EGTA $\mathrm{Mg}^{++}$buffer. In this system, however, the auto-activation ("tick-over") of C3 and the AP pathway amplification is intact (51-54) and would permit slow continuous C3b deposition, making it difficult to demonstrate whether fP reacts as an initial pattern recognition molecule or binds secondarily after initial $\mathrm{C} 3 \mathrm{~b}$ deposition on a reactive surface.

The authors of the studies describing properdin as recognition molecule $(2,14)$ noted that purified properdin may react differently from properdin in serum due to the "tick-over" reaction. Properdin released from activated, degranulated neutrophils may also react differently from properdin in serum (15). Our data clearly indicate that plasma and serum fP and fP released from PMN cells behave similarly with respect to binding to zymosan and $E$. coli. Notably, PMN-released fP did not bind unless incubated in fPd serum. Then efficient binding took place, but was completely abolished by compstatin, exactly as seem for serum fP.

In contrast to our findings with exogenous ligands (zymosan and $E$. coli), compelling evidence for C3 independent direct fP binding to endogenous ligands, i.e. late apoptotic or necrotic cells (55), was based on a set of different, independent criteria: binding was demonstrated after incubation of the cells with purified human fP in serum-free RPMI culture medium, purified fP bound to necrotic splenocytes of $\mathrm{C} 3$ knockout $\left(\mathrm{C} 3^{-/-}\right)$mice like to cells from wild type mice, and purified fP bound to necrotic cells in C3-deficient serum in EDTA containing medium, like binding in NHS. The ligand involved in fP binding was studied by confocal microscopy confirming that fP was co localized exclusively with fragmented DNA exposed on late apoptotic cells. This is direct evidence for fP reactivity as recognition molecule of endogenous ligands under certain conditions.

Purified fP often forms a series of oligomers of a 53,000 $\mathrm{Mr}$ subunit, assembling into dimers $\left(\mathrm{P}_{2}\right)$, trimers $\left(\mathrm{P}_{3}\right)$, tetramers $\left(\mathrm{P}_{4}\right)$ and higher forms $\left(\mathrm{P}_{\mathrm{n}}\right)$ which can be separated by cation exchange chromatography and gel filtration(16). In this study, unseparated purified fP and $P_{n}$ was found to bind to live Raji and Jurkat cells while physiological forms of fP $\left(P_{2}\right.$, $\mathrm{P}_{3}$, and $\mathrm{P}_{4}$ ) only bound to necrotic and Jurkat cells. The live and necrotic cells were incubated with different forms of fP in Hank's buffered saline solution for $1 \mathrm{~h}$ at $37^{\circ} \mathrm{C}$, washed, and analyzed by FACS with an anti-fP mAb or an IgG1 mAb isotype control, followed by an FITC-conjugated anti-mouse IgG antibody. This procedure clearly indicates C3-independence of the physiological forms of fP binding to necrotic Raji and Jurkat cells.

To explore whether fP bound initially as a recognition molecule with initial activating function or participated as amplifier of AP after initial C3b deposition, we performed 
inhibition experiments with the $\mathrm{C} 3$ reactive peptide compstatin. Compstatin was the first non-host-derived complement inhibitor shown to block the CP, LP and AP activation pathways (26). This 13-residue cyclic peptide was discovered by a phage-display, random peptide library search. Analogues with markedly increased potency (V4W, H9A) were later identified (27). These compounds bind $\mathrm{C} 3, \mathrm{C} 3\left(\mathrm{H}_{2} \mathrm{O}\right), \mathrm{C} 3 \mathrm{~b}$, and $\mathrm{C} 3 \mathrm{c}$ with high specificity, inhibiting complement activation (56). The crystal structure of compstatin in complex with $\mathrm{C} 3 \mathrm{c}$ has been presented (28). The compstatin binding site is formed by the macroglobulin (MG) domains 4 and 5. A model was proposed in which compstatin sterically hinders the access of substrate $\mathrm{C} 3$ to the convertase complexes thus blocking complement activation and amplification (28). In the present experiments, compstatin completely inhibited fP binding to zymosan in ELISA, while deposition of $\mathrm{C} 4 \mathrm{~b}$, occurring earlier in the cascade, was not inhibited. By contrast, $\mathrm{C} 4 \mathrm{~b}$ deposition was increased in the presence of compstatin, most likely due to increased availability of acceptor sites for covalent binding of $\mathrm{C} 4 \mathrm{~b}$ in the absence of $\mathrm{C} 3 \mathrm{~b}$.

Inhibition by anti-fD was incomplete, while anti-fP inhibited fP deposition completely at all zymosan concentrations tested (Fig. 4A). To explain the latter distinction, an interaction of fP with C3b independent of fD would need to occur. In Surface Plasmon Resonance (SPR) spectroscopy, fP has been shown to bind strongly to $\mathrm{C} 3 \mathrm{~b}$ and $\mathrm{C} 3 \mathrm{bB}$ without further action of fD (14) explaining the finding of complete inhibition by anti-fP.

The importance of fP reactivity in vivo has been studied in murine autoimmune models by using gene-targeted fP deficient mice in studies of zymosan-induced arthritis (57). Further, fP deficiency rescued mice from AP complement-mediated embryonic lethality cased by deficiency of the membrane complement regulator Crry and markedly reduced disease severity in the $\mathrm{K} / \mathrm{BxN}$ model of arthritis (58). In the present in vitro studies fP reactivity with the exogenous antigens zymosan and $E$. coli $\mathrm{C} 3$ b dependence was demonstrated, while $\mathrm{C} 3 \mathrm{~b}$ independence and direct $\mathrm{fP}$ activity as recognition molecule was seen with selected endogenous antigens, such as necrotic and late apoptotic cells $(16,55)$, whereas the paper by Ferreira et al.(16) showed that fP bound to zymosan as well.

The reaction pattern of purified $\mathrm{fP}$ and $\mathrm{fP}$ in serum has revealed some striking differences, e.g. in reaction with apoptotic T-cells (15). Purified fP bound to apoptotic T-cells while similar binding of fP in serum to the apoptotic cells was C3 dependent. Additional experiments indicated that fP freshly released from activated, degranulating neutrophils bound to apoptotic T-cells while endogenous fP in serum is strictly regulated. These observations appear directly related to complement involvement in neutrophil-mediated diseases (59).

In our experiments we included both serum and lepirudin plasma, the latter to get as close to physiological conditions as possible. All results were comparable. Thus we conclude that binding of fP in human serum and plasma, as well as fP released from PMN cells $(59,60)$, to zymosan and $E$. coli was C3-dependent, indicating an initial binding of C3b followed by secondary binding of fP. Similar observations were made in another just published study showing that fP in serum bound to glycan particles and zymosan "only in the presence of active C3" (61). In this study the authors showed binding of fP in flow cytometry after incubation of glycan particles and zymosan in NHS in EGTA $\mathrm{Mg}^{++}$buffer. Binding of fP was not obtained in $\mathrm{C} 3$-depleted serum, but in the $\mathrm{C} 3$-depleted serum reconstituted with purified C3. Another recent study showed that the tissue damage in an elastase-induced mouse model of abdominal aortic aneurysm depended on AP activation, being C3dependent (62). Direct binding of purified fP as recognition molecule has been demonstrated in other circumstances $(16,55)$. Our study indicates that inhibition experiments with 
compstatin are valuable to identify additional settings in which fP reacts as recognition molecule.

\section{Supplementary Material}

Refer to Web version on PubMed Central for supplementary material.

\section{Acknowledgments}

This work was supported by The Norwegian Research Council, The Norwegian Council on Cardiovascular Disease, The Odd Fellow Foundation and the NIH grants AI068730 and GM60338 to JDL.

We thank Wenchao Song for valuable comments to the manuscript.

\section{References}

1. Pillemer L, Blum L, Lepow IH, Ross OA, Todd EW, Wardlaw AC. The properdin system and immunity. I. Demonstration and isolation of a new serum protein, properdin, and its role in immune phenomena. Science. 1954; 120:279-285. [PubMed: 13186838]

2. Spitzer D, Mitchell LM, Atkinson JP, Hourcade DE. Properdin can initiate complement activation by binding specific target surfaces and providing a platform for de novo convertase assembly. $\mathrm{J}$ Immunol. 2007; 179:2600-2608. [PubMed: 17675523]

3. Ecker EE. Louis Pillemer; 1908-1957. J Immunol. 1958; 80:415-416. [PubMed: 13549726]

4. Lepow IH. Presidential address to American Association of Immunologists in Anaheim, California, April 16, 1980. Louis Pillemer, Properdin, and scientific controversy. J Immunol. 1980; 125:471475. [PubMed: 6993558]

5. Lachmann P. Complement before molecular biology. Mol Immunol. 2006; 43:496-508. [PubMed: 15890405]

6. Kimura Y, Miwa T, Zhou L, Song WC. Activator-specific requirement of properdin in the initiation and amplification of the alternative pathway complement. Blood. 2008; 111:732-740. [PubMed: 17916747]

7. Stover CM, Luckett JC, Echtenacher B, Dupont A, Figgitt SE, Brown J, Mannel DN, Schwaeble WJ. Properdin plays a protective role in polymicrobial septic peritonitis. J Immunol. 2008; 180:3313-3318. [PubMed: 18292556]

8. Harboe M, Mollnes TE. The alternative complement pathway revisited. J Cell Mol Med. 2008; 12:1074-1084. [PubMed: 18419792]

9. Kemper C, Atkinson JP, Hourcade DE. Properdin: emerging roles of a pattern-recognition molecule. Annu Rev Immunol. 2010; 28:131-155. [PubMed: 19947883]

10. Medicus RG, Gotze O, Muller-Eberhard HJ. Alternative pathway of complement: recruitment of precursor properdin by the labile $\mathrm{C} 3 / \mathrm{C} 5$ convertase and the potentiation of the pathway. J Exp Med. 1976; 144:1076-1093. [PubMed: 978134]

11. Pangburn MK, Muller-Eberhard HJ. The C3 convertase of the alternative pathway of human complement. Enzymic properties of the bimolecular proteinase. Biochem J. 1986; 235:723-730. [PubMed: 3638964]

12. Fearon DT, Austen KF. Properdin: binding to C3b and stabilization of the C3b-dependent $\mathrm{C} 3$ convertase. J Exp Med. 1975; 142:856-863. [PubMed: 1185108]

13. Fearon DT. Activation of the alternative complement pathway. CRC Crit Rev Immunol. 1979; 1:132. [PubMed: 162484]

14. Hourcade DE. The role of properdin in the assembly of the alternative pathway $\mathrm{C} 3$ convertases of complement. J Biol Chem. 2006; 281:2128-2132. [PubMed: 16301317]

15. Kemper C, Mitchell LM, Zhang L, Hourcade DE. The complement protein properdin binds apoptotic T cells and promotes complement activation and phagocytosis. Proc Natl Acad Sci U S A. 2008; 105:9023-9028. [PubMed: 18579773] 
16. Ferreira VP, Cortes C, Pangburn MK. Native polymeric forms of properdin selectively bind to targets and promote activation of the alternative pathway of complement. Immunobiology. 2010; 215:932-940. [PubMed: 20382442]

17. Krarup A, Thiel S, Hansen A, Fujita T, Jensenius JC. L-ficolin is a pattern recognition molecule specific for acetyl groups. J Biol Chem. 2004; 279:47513-47519. [PubMed: 15331601]

18. Garred P, Honore C, Ma YJ, Rorvig S, Cowland J, Borregaard N, Hummelshoj T. The genetics of ficolins. J Innate Immun. 2010; 2:3-16. [PubMed: 20375618]

19. Gout E, Garlatti V, Smith DF, Lacroix M, Dumestre-Perard C, Lunardi T, Martin L, Cesbron JY, Arlaud GJ, Gaboriaud C, Thielens NM. Carbohydrate recognition properties of human ficolins: glycan array screening reveals the sialic acid binding specificity of M-ficolin. J Biol Chem. 2010; 285:6612-6622. [PubMed: 20032467]

20. Harboe M, Garred P, Borgen MS, Stahl GL, Roos A, Mollnes TE. Design of a complement mannose-binding lectin pathway-specific activation system applicable at low serum dilutions. Clin Exp Immunol. 2006; 144:512-520. [PubMed: 16734621]

21. Suankratay C, Zhang XH, Zhang Y, Lint TF, Gewurz H. Requirement for the alternative pathway as well as $\mathrm{C} 4$ and $\mathrm{C} 2$ in complement-dependent hemolysis via the lectin pathway. $\mathrm{J}$ Immunol. 1998; 160:3006-3013. [PubMed: 9510205]

22. Brouwer N, Dolman KM, van ZR, Nieuwenhuys E, Hart M, Aarden LA, Roos D, Kuijpers TW. Mannan-binding lectin (MBL)-mediated opsonization is enhanced by the alternative pathway amplification loop. Mol Immunol. 2006; 43:2051-2060. [PubMed: 16499969]

23. Zhao H, Wakamiya N, Suzuki Y, Hamonko MT, Stahl GL. Identification of human mannose binding lectin (MBL) recognition sites for novel inhibitory antibodies. Hybrid Hybridomics. 2002; 21:25-36. [PubMed: 11991814]

24. Harboe M, Ulvund G, Vien L, Fung M, Mollnes TE. The quantitative role of alternative pathway amplification in classical pathway induced terminal complement activation. Clin Exp Immunol. 2004; 138:439-446. [PubMed: 15544620]

25. Harboe M, Garred P, Karlstrom E, Lindstad JK, Stahl GL, Mollnes TE. The down-stream effects of mannan-induced lectin complement pathway activation depend quantitatively on alternative pathway amplification. Mol Immunol. 2009; 47:373-380. [PubMed: 19800125]

26. Sahu A, Kay BK, Lambris JD. Inhibition of human complement by a C3-binding peptide isolated from a phage-displayed random peptide library. J Immunol. 1996; 157:884-891. [PubMed: 8752942]

27. Mallik B, Katragadda M, Spruce LA, Carafides C, Tsokos CG, Morikis D, Lambris JD. Design and NMR characterization of active analogues of compstatin containing non-natural amino acids. $\mathbf{J}$ Med Chem. 2005; 48:274-286. [PubMed: 15634022]

28. Janssen BJ, Halff EF, Lambris JD, Gros P. Structure of compstatin in complex with complement component C3c reveals a new mechanism of complement inhibition. J Biol Chem. 2007; 282:29241-29247. [PubMed: 17684013]

29. Magotti P, Ricklin D, Qu H, Wu YQ, Kaznessis YN, Lambris JD. Structure-kinetic relationship analysis of the therapeutic complement inhibitor compstatin. J Mol Recognit. 2009; 22:495-505. [PubMed: 19658192]

30. Hourcade DE. Properdin and complement activation: a fresh perspective. Curr Drug Targets. 2008; 9:158-164. [PubMed: 18288967]

31. Collard CD, Vakeva A, Morrissey MA, Agah A, Rollins SA, Reenstra WR, Buras JA, Meri S, Stahl GL. Complement activation after oxidative stress: role of the lectin complement pathway. Am J Pathol. 2000; 156:1549-1556. [PubMed: 10793066]

32. Fung M, Loubser PG, Undar A, Mueller M, Sun C, Sun WN, Vaughn WK, Fraser CD Jr. Inhibition of complement, neutrophil, and platelet activation by an anti-factor D monoclonal antibody in simulated cardiopulmonary bypass circuits. J Thorac Cardiovasc Surg. 2001; 122:113122. [PubMed: 11436043]

33. Mollnes TE, Lea T, Froland SS, Harboe M. Quantification of the terminal complement complex in human plasma by an enzyme-linked immunosorbent assay based on monoclonal antibodies against a neoantigen of the complex. Scand J Immunol. 1985; 22:197-202. [PubMed: 2412280] 
34. Seelen MA, Roos A, Wieslander J, Mollnes TE, Sjoholm AG, Wurzner R, Loos M, Tedesco F, Sim RB, Garred P, Alexopoulos E, Turner MW, Daha MR. Functional analysis of the classical, alternative, and MBL pathways of the complement system: standardization and validation of a simple ELISA. J Immunol Methods. 2005; 296:187-198. [PubMed: 15680163]

35. Harboe M, Closs O, Reitan LJ, Draper P. Demonstration of antibodies reacting with different determinants on Mycobacterium leprae antigen 7. Int J Lepr Other Mycobact Dis. 1981; 49:147158. [PubMed: 6168595]

36. Laursen I, Houen G, Hojrup P, Brouwer N, Krogsoe LB, Blou L, Hansen PR. Second-generation nanofiltered plasma-derived mannan-binding lectin product: process and characteristics. Vox Sang. 2007; 92:338-350. [PubMed: 17456158]

37. Garred P, Larsen F, Madsen HO, Koch C. Mannose-binding lectin deficiency--revisited. Mol Immunol. 2003; 40:73-84. [PubMed: 12914814]

38. Larsen F, Madsen HO, Sim RB, Koch C, Garred P. Disease-associated mutations in human mannose-binding lectin compromise oligomerization and activity of the final protein. J Biol Chem. 2004; 279:21302-21311. [PubMed: 14764589]

39. Larsson K, Wester K, Nilsson P, Uhlen M, Hober S, Wernerus H. Multiplexed PrEST immunization for high-throughput affinity proteomics. J Immunol Methods. 2006; 315:110-120. [PubMed: 16949094]

40. Persson A, Hober S, Uhlen M. A human protein atlas based on antibody proteomics. Curr Opin Mol Ther. 2006; 8:185-190. [PubMed: 16774037]

41. Hopp TP, Woods KR. Prediction of protein antigenic determinants from amino acid sequences. Proc Natl Acad Sci U S A. 1981; 78:3824-3828. [PubMed: 6167991]

42. Mollnes TE, Lea T, Harboe M, Tschopp J. Monoclonal antibodies recognizing a neoantigen of poly(C9) detect the human terminal complement complex in tissue and plasma. Scand J Immunol. 1985; 22:183-195. [PubMed: 4035298]

43. Mollnes TE, Redl H, Hogasen K, Bengtsson A, Garred P, Speilberg L, Lea T, Oppermann M, Gotze O, Schlag G. Complement activation in septic baboons detected by neoepitope-specific assays for $\mathrm{C} 3 \mathrm{~b} / \mathrm{iC} 3 \mathrm{~b} / \mathrm{C} 3 \mathrm{c}, \mathrm{C} 5 \mathrm{a}$ and the terminal C5b-9 complement complex (TCC). Clin Exp Immunol. 1993; 91:295-300. [PubMed: 7679061]

44. Hein E, Honore C, Skjoedt MO, Munthe-Fog L, Hummelshoj T, Garred P. Functional analysis of Ficolin-3 mediated complement activation. PLoS One. 2010; 5:e15443. [PubMed: 21085669]

45. Kjaer TR, Hansen AG, Sorensen UB, Nielsen O, Thiel S, Jensenius JC. Investigations on the pattern recognition molecule M-ficolin: quantitative aspects of bacterial binding and leukocyte association. J Leukoc Biol. 2011; 90:425-437. [PubMed: 21730084]

46. Thomsen T, Schlosser A, Holmskov U, Sorensen GL. Ficolins and FIBCD1: soluble and membrane bound pattern recognition molecules with acetyl group selectivity. Mol Immunol. 2011; 48:369-381. [PubMed: 21071088]

47. Mollnes TE, Brekke OL, Fung M, Fure H, Christiansen D, Bergseth G, Videm V, Lappegard KT, Kohl J, Lambris JD. Essential role of the C5a receptor in E coli-induced oxidative burst and phagocytosis revealed by a novel lepirudin-based human whole blood model of inflammation. Blood. 2002; 100:1869-1877. [PubMed: 12176911]

48. Lappegard KT, Christiansen D, Pharo A, Thorgersen EB, Hellerud BC, Lindstad J, Nielsen EW, Bergseth G, Fadnes D, Abrahamsen TG, Hoiby EA, Schejbel L, Garred P, Lambris JD, Harboe M, Mollnes TE. Human genetic deficiencies reveal the roles of complement in the inflammatory network: lessons from nature. Proc Natl Acad Sci U S A. 2009; 106:15861-15866. [PubMed: 19717455]

49. Harboe M, Thorgersen EB, Mollnes TE. Advances in assay of complement function and activation. Adv Drug Deliv Rev. 2011; 63:976-987. [PubMed: 21664392]

50. Phillips AE, Toth J, Dodds AW, Girija UV, Furze CM, Pala E, Sim RB, Reid KB, Schwaeble WJ, Schmid R, Keeble AH, Wallis R. Analogous interactions in initiating complexes of the classical and lectin pathways of complement. J Immunol. 2009; 182:7708-7717. [PubMed: 19494295]

51. Lachmann PJ, Halbwachs L. The influence of C3b inactivator (KAF) concentration on the ability of serum to support complement activation. Clin Exp Immunol. 1975; 21:109-114. [PubMed: 52423] 
52. Pangburn MK, Schreiber RD, Muller-Eberhard HJ. Formation of the initial C3 convertase of the alternative complement pathway. Acquisition of C3b-like activities by spontaneous hydrolysis of the putative thioester in native C3. J Exp Med. 1981; 154:856-867. [PubMed: 6912277]

53. Pangburn MK, Muller-Eberhard HJ. Initiation of the alternative complement pathway due to spontaneous hydrolysis of the thioester of C3. Ann N Y Acad Sci. 1983; 421:291-298. [PubMed: 6586103]

54. Bexborn F, Andersson PO, Chen H, Nilsson B, Ekdahl KN. The tick-over theory revisited: Formation and regulation of the soluble alternative complement $\mathrm{C} 3$ convertase $(\mathrm{C} 3(\mathrm{H}(2) \mathrm{O}) \mathrm{Bb})$. Mol Immunol. 2008; 45:2370-2379. [PubMed: 18096230]

55. Xu W, Berger SP, Trouw LA, de Boer HC, Schlagwein N, Mutsaers C, Daha MR, van KC. Properdin binds to late apoptotic and necrotic cells independently of $\mathrm{C} 3 \mathrm{~b}$ and regulates alternative pathway complement activation. J Immunol. 2008; 180:7613-7621. [PubMed: 18490764]

56. Sahu A, Soulika AM, Morikis D, Spruce L, Moore WT, Lambris JD. Binding kinetics, structureactivity relationship, and biotransformation of the complement inhibitor compstatin. J Immunol. 2000; 165:2491-2499. [PubMed: 10946275]

57. Dimitrova P, Ivanovska N, Schwaeble W, Gyurkovska V, Stover C. The role of properdin in murine zymosan-induced arthritis. Mol Immunol. 2010; 47:1458-1466. [PubMed: 20226532]

58. Kimura Y, Zhou L, Miwa T, Song WC. Genetic and therapeutic targeting of properdin in mice prevents complement-mediated tissue injury. J Clin Invest. 2010; 120:3545-3554. [PubMed: 20941861]

59. Camous L, Roumenina L, Bigot S, Brachemi S, Fremeaux-Bacchi V, Lesavre P, HalbwachsMecarelli L. Complement alternative pathway acts as a positive feedback amplification of neutrophil activation. Blood. 2011; 117:1340-1349. [PubMed: 21063021]

60. Wirthmueller U, Dewald B, Thelen M, Schafer MK, Stover C, Whaley K, North J, Eggleton P, Reid KB, Schwaeble WJ. Properdin, a positive regulator of complement activation, is released from secondary granules of stimulated peripheral blood neutrophils. J Immunol. 1997; 158:44444451. [PubMed: 9127010]

61. Agarwal S, Specht CA, Haibin H, Ostroff GR, Ram S, Rice PA, Levitz SM. Linkage specificity and role of properdin in activation of the alternative complement pathway by fungal glycans. MBio. 2011:2.

62. Pagano MB, Zhou HF, Ennis TL, Wu X, Lambris JD, Atkinson JP, Thompson RW, Hourcade DE, Pham CT. Complement-dependent neutrophil recruitment is critical for the development of elastase-induced abdominal aortic aneurysm. Circulation. 2009; 119:1805-1813. [PubMed: 19307471] 

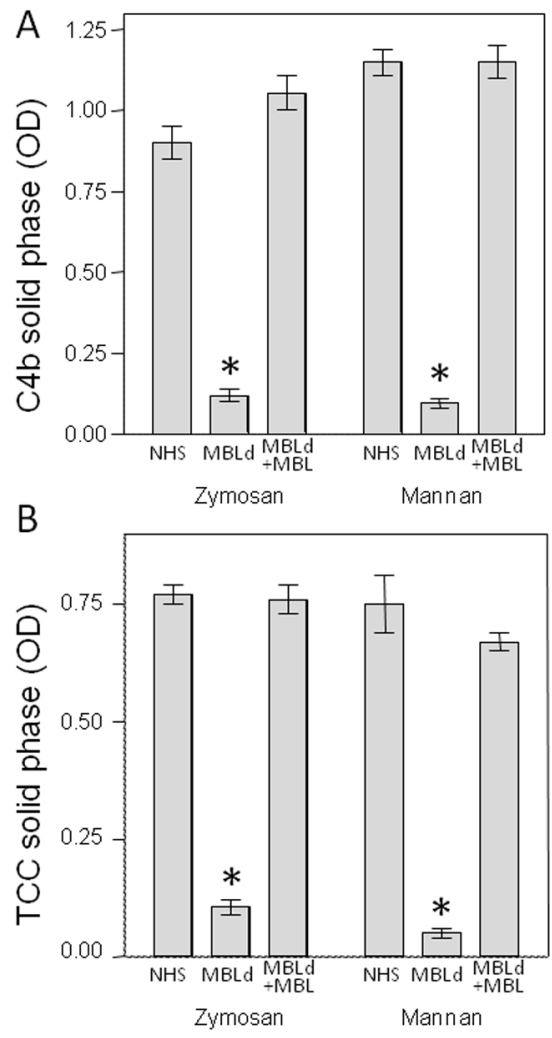

FIGURE 1.

Reaction pattern of normal human serum (NHS) compared with MBL deficient (MBLd) serum after activation with zymosan on the solid phase, $0.5 \mu \mathrm{g} /$ well. Reconstitution with 10 $\mu \mathrm{g}$ purified $\mathrm{MBL} / \mathrm{ml} \mathrm{MBLd}$ serum showed distinct activation with increasing OD values for deposition of $\mathrm{C} 4 \mathrm{~b}$ and TCC on the solid phase. Data are presented as mean values and range from two independent experiments. At the right mannan coating on the solid phase $(0.5 \mu \mathrm{g} /$ w) for comparison. Typical finding in four experiments. $*=p<0.05$. 


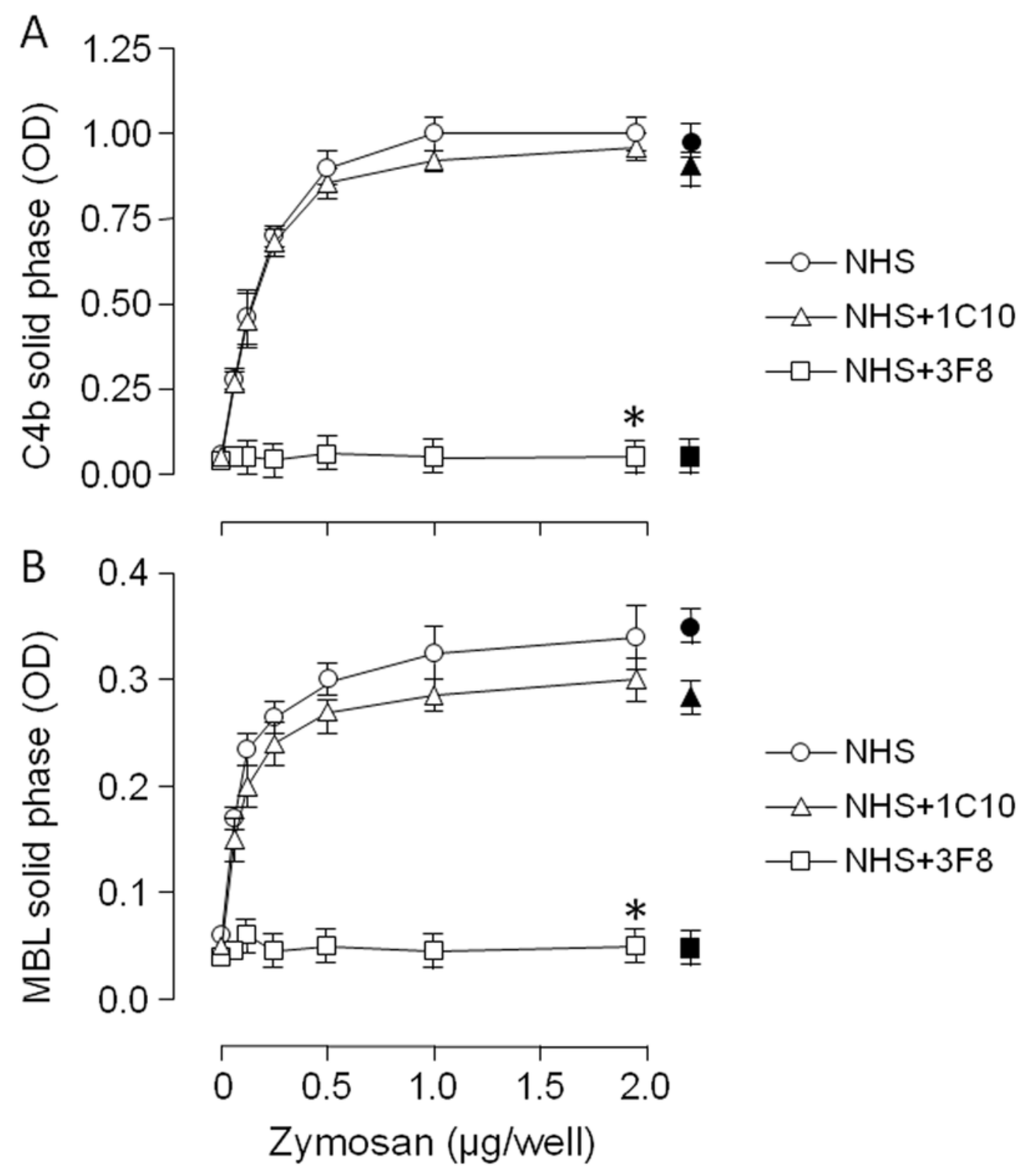

FIGURE 2.

Deposition of C4b (A) and MBL (B) on the solid phase after activation of NHS by different amounts of zymosan on the solid phase. 3F8 and 1C10 = anti-MBL inhibiting and noninhibiting monoclonal antibodies respectively. At the right, in black, mannan coating ( 0.5 $\mu \mathrm{g} / \mathrm{w}$ ) for comparison. Typical finding in four experiments. $*=\mathrm{p}<0.05$. 


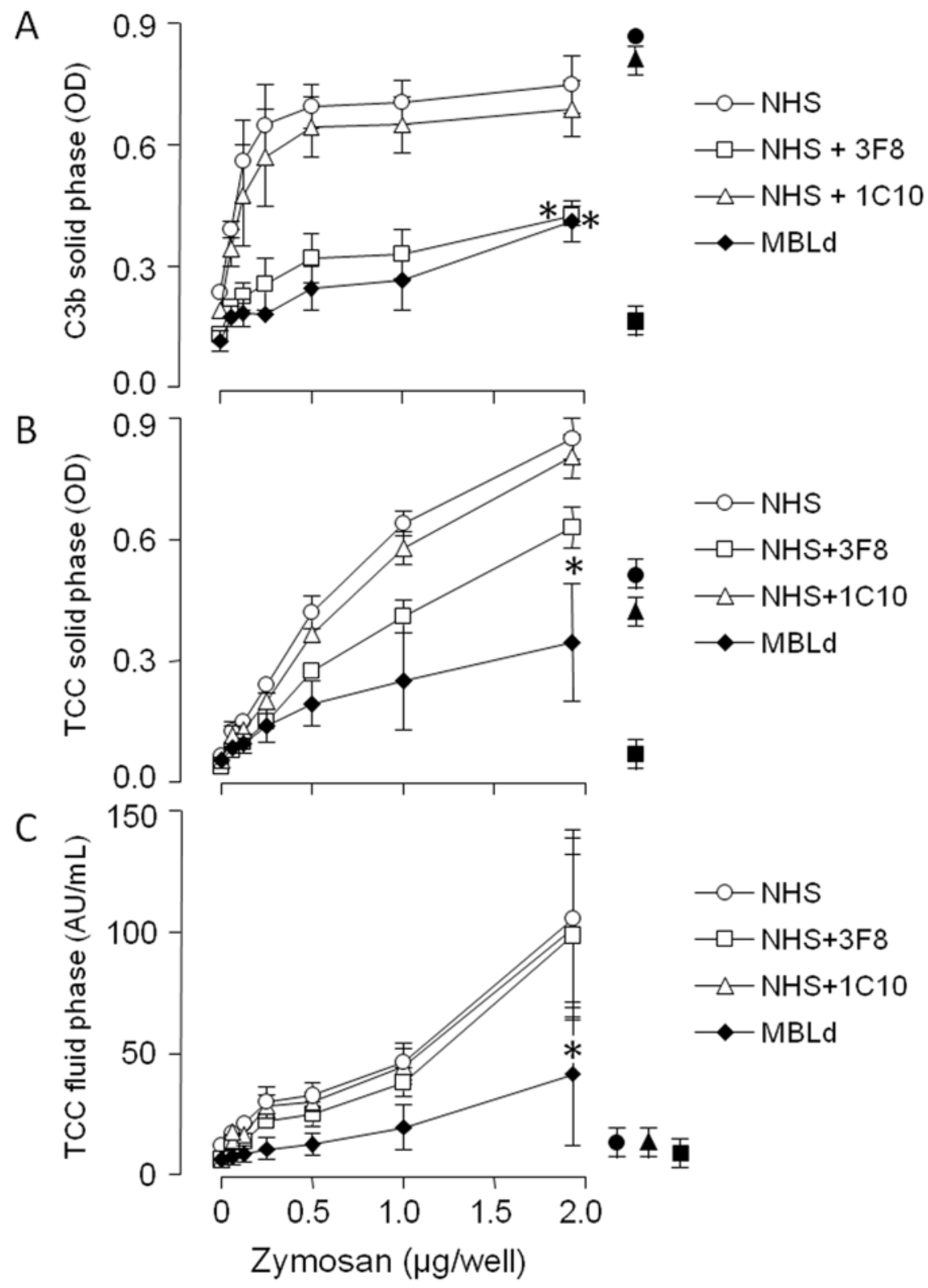

FIGURE 3.

Deposition of C3b (A) and TCC (B) on the solid phase and release of TCC into the fluid phase (C) after activation of NHS by different amounts of zymosan on the solid phase. Description and data presentation as in Fig. 2. Typical finding in four experiments. $*=p<$ 0.05 . 

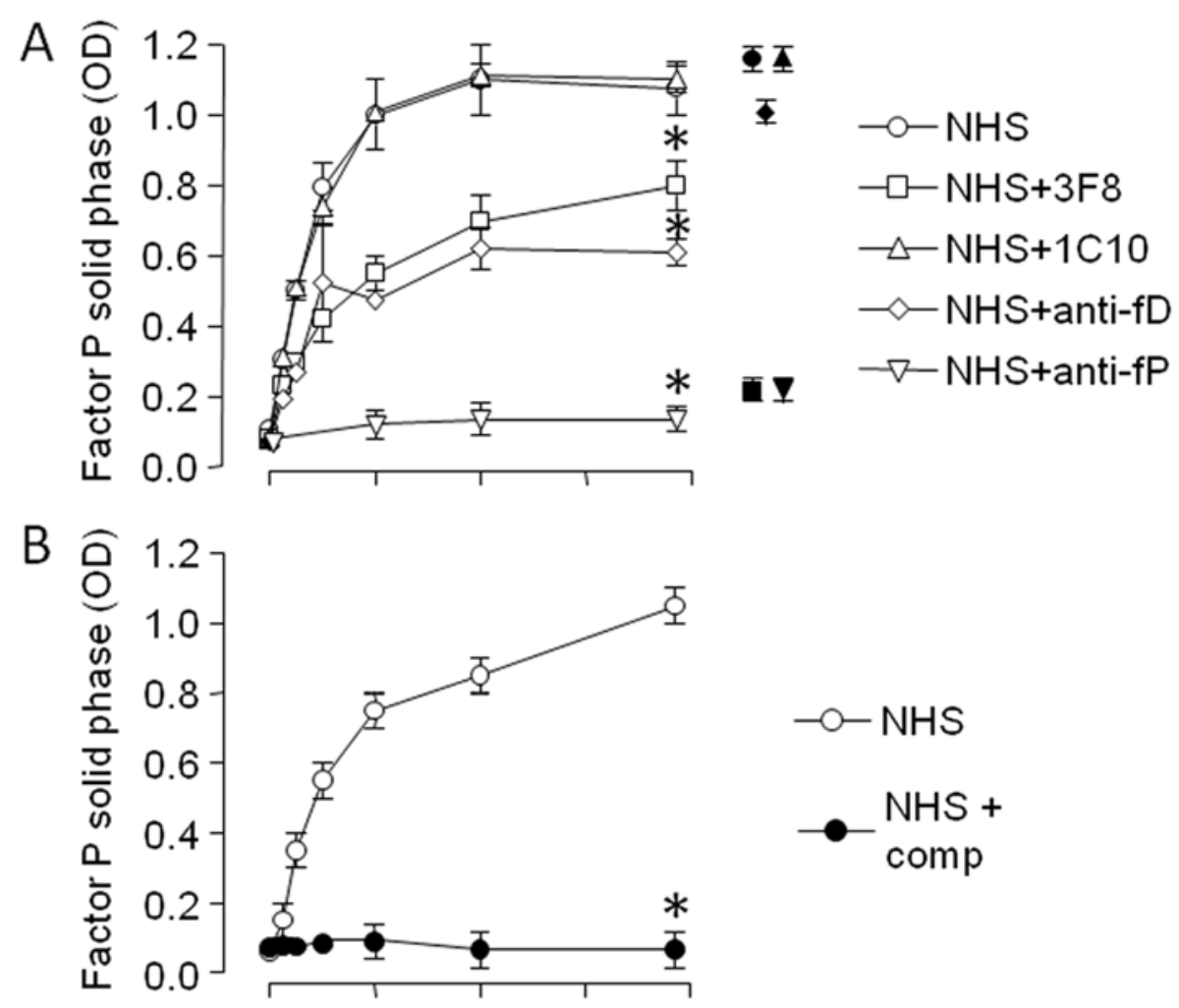

$-0-$ NHS

$\mathrm{NHS}+$

C
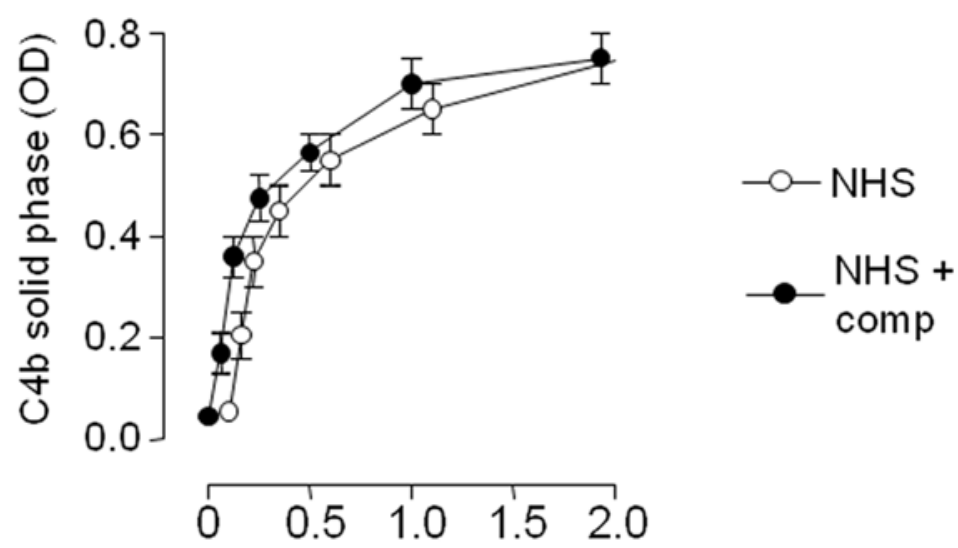

Zymosan ( $\mu \mathrm{g} /$ well)

FIGURE 4.

Inhibition of deposition of $\mathrm{fP}$ on the solid phase by anti-MBL, anti-fD (a-fD) and anti-fP (afP) monoclonal antibodies after activation of NHS by different amounts of zymosan on the solid phase (A). Description and data presentation as in Fig. 2. Effect of adding compstatin to serum $(50 \mu \mathrm{M} / \mathrm{ml})$ on deposition of $\mathrm{fP}(\mathrm{B})$ and $\mathrm{C} 4 \mathrm{~b}(\mathrm{C})$ on the solid phase after activation of NHS by different amounts of zymosan on the solid phase. Typical finding in four experiments. $*=\mathrm{p}<0.05$. 

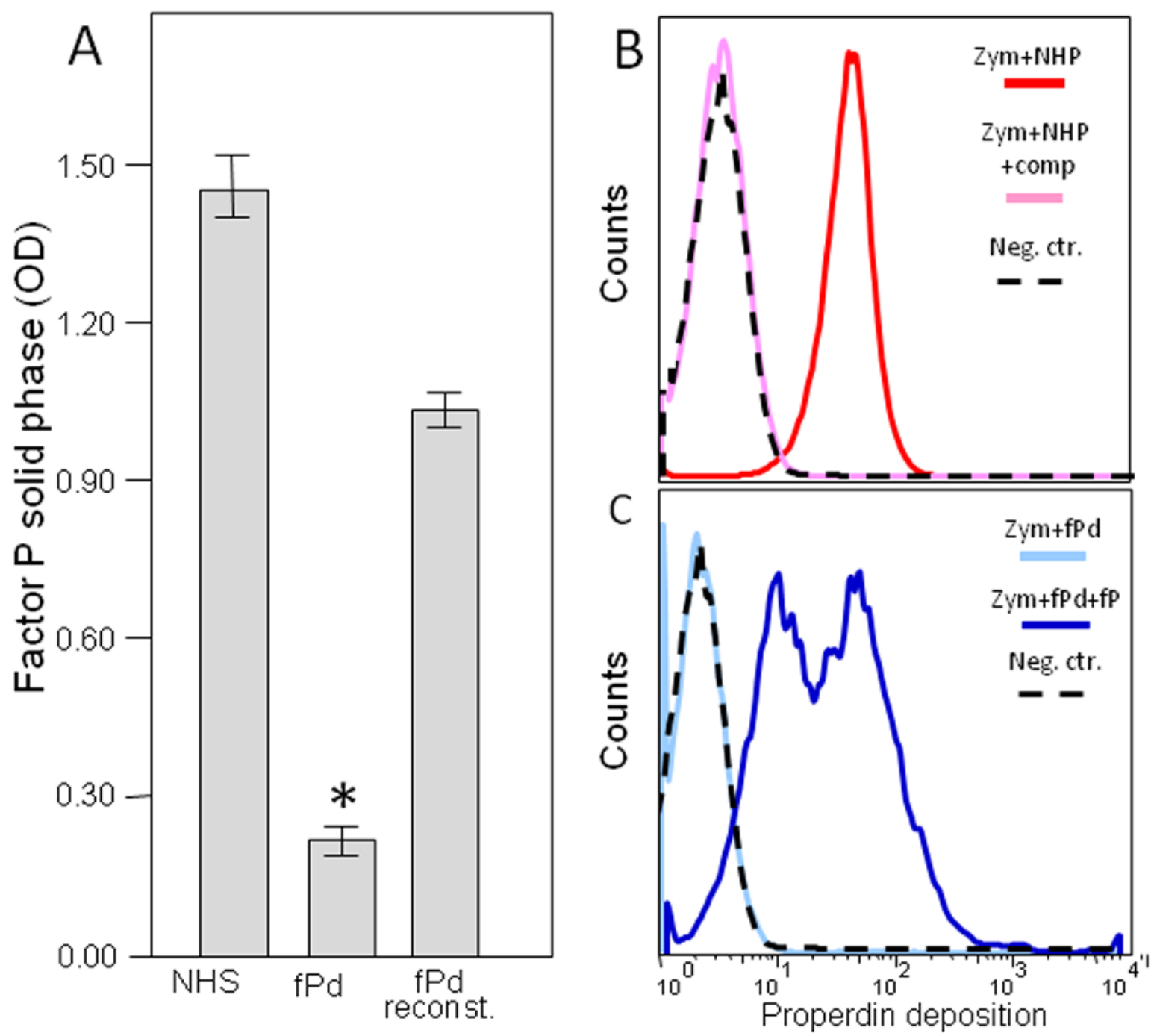

FIGURE 5.

Deposition of $\mathrm{fP}$ on the solid phase in ELISA after incubation of zymosan with NHS compared with fPd serum and fPd serum reconstituted with purified fP (A). Flow cytometry showing deposition of fP on zymosan after activation of NHP (dark red curve) and inhibition by compstatin (light red curve) with isotype control in the black stippled curve (B). Similar experiment to compare zymosan reactivity with fPd serum and fPd serum reconstituted with purified $\mathrm{fP}(\mathrm{C}) . * \mathrm{p}<0.05$. 

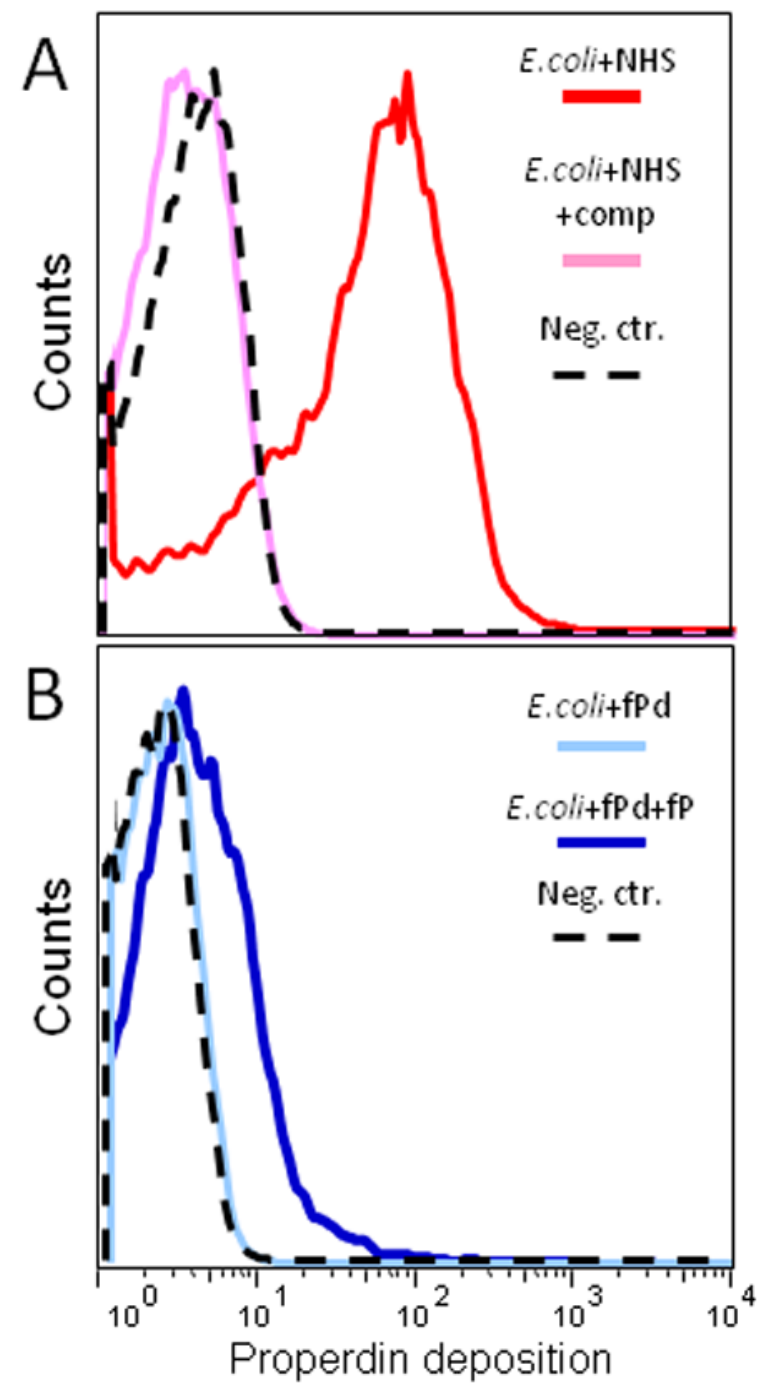

FIGURE 6.

Flow cytometry to show deposition of fP in normal human serum 1:2 on E. coli (dark red curve) and effect of compstatin (light red curve). Deposition of fP was detected by reaction with anti-fP $\mathrm{mAb}$ and FITC-conjugated anti-mouse IgG. Control replacing anti-fP $\mathrm{mAb}$ with its isotype control (stippled black curve) (A). The same layout with fPd serum in light blue and reconstitution with $\mathrm{fP}$ in dark blue (B). Similar findings in six experiments on three $E$. coli strains. 

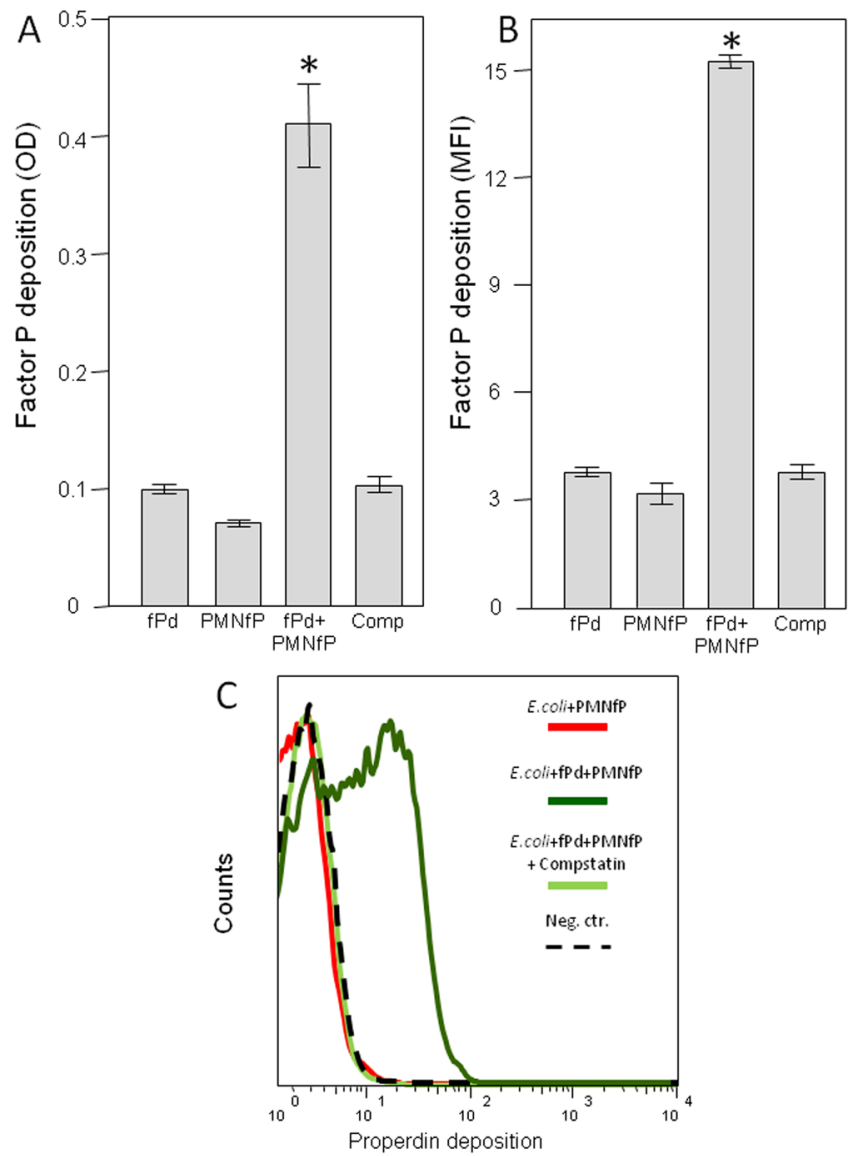

FIGURE 7.

Deposition of PMN released fP (PMNfP) on the solid phase in ELISA after incubation of zymosan with fPd serum, PMNfP, PMNfP incubated in fPd serum, and the latter inhibited with compstatin (Comp) (A). Flow cytometry showing PMNfP deposition on E. coli bacteria with same experimental design as described in A (B). Histogram from one representative experiment described in B, showing PMNfP (red curve), PMNfP incubated in fPd serum (dark green curve), and the latter inhibited with compstatin (light green curve). The isotype control (black stippled curve) (C). * $=\mathrm{p}<0.05$. 